\title{
PREVALENCE OF YEAST IN SOME CHICKEN MEAT PRODUCTS
}

\author{
DOAA A.H. EL-MATARY* and NASHOWA M. ZAKI ${ }^{* *}$ \\ *Department of Mycology, Animal Health Research Institute, Dokki, Gizza, El-Mansoura Provincial Laboratory \\ 'Department of food control, Animal Health Research Institute, Dokki, Gizza, El-Mansoura Provincial \\ Laboratory
}

Received: 30 June 2016; Accepted: 31 July 2016

\begin{abstract}
This study was carried out upon 60 samples of chicken luncheon, pane and nuggets (20 of each), samples were collected from different markets at Dakhlia governorate and conducted to evaluate the total yeast count and the mycological profiles. The mean values of the total yeast counts of chicken luncheon, pane and nuggets (cfu/g) were $7.1 \times 10^{3} \pm 3.1 \times 10^{3}, 1.8 \times 10^{5} \pm 8.2 \times 10^{4}, 2.4 \times 10^{6} \pm 1.4 \times 10^{6}$, respectively. There was a significant difference in total yeast count between chicken luncheon and nuggets. Chicken nuggets were the most contaminated samples with yeast, while chicken luncheon was the lowest contaminated samples. One hundred and five (105) yeast isolates represented 4 genera were isolated from chicken luncheon, pane and nuggets samples in the following number and percentage, Candida, 14 (58.3\%), 22(59.5\%), 25(56.8\%) with the highest total incidence of 61(58\%) followed by Rhodotorula 7(29.1\%), 11(29.7), 13(29.5\%) with total incidence of 31(29.5\%) followed by Saccharomyces, $3(12.5 \%), 3(8.1 \%), 4(9.1 \%)$ with total incidence 10(9.5\%), and finally, Trichosporon $0(0 \%), 1(2.7 \%), 2(4.5 \%)$ with total incidence $3(2.9 \%)$, respectively. Regarding yeast species isolated from chicken luncheon, pane and nuggets, C. albicans were the most predominant species which isolated from $40 \%$, $75 \%$ and $85 \%$ of examined samples represented by the following number and percentage $8(33.3 \%), 15(40.5 \%)$ and $17(38.6 \%)$, respectively. The yeast isolates were identified using traditional standard method. Six samples examined using PCR, all of them were successfully amplified a products of $109 \mathrm{bp}$ and interpreted as positive for Candida albicans which confirmed the results obtained by traditional method. While 2 samples amplified a products of $919 \mathrm{bp}$ and proved to be positive for killer gene (KHS) of S. cerviciae and one samples amplified a product of 727 bp and give positive killer genes (PelA).
\end{abstract}

Key words: Yeast, total count, identification, Chicken luncheon, nuggets, pane, PCR.

\section{INTRODUCTION}

Chicken and chicken meat products are a good sources of animal protein of high biological values which contains all essential amino acids required for human nutrition, as well as they contains higher proportion of unsaturated fatty acid and less cholesterol besides, poultry meat is good source of different types of vitamins (Shedeed, 1999 and Abo Hussein, 2007).

Yeast is microscopic single organisms which are mostly saprophytic, while few species are pathogenic (Abd-El-Rhahman et al., 2013). Yeast can contaminated chicken meat and their products during processing as scalding, defeathering, evisceration,

Corresponding author: Dr. DOAA A.H. EL-MATARY E-mail address: doaaelmatry@yahoo.com

Present address: Department of Mycology, Animal Health Research Institute, Dokki, Gizza, El-Mansoura Provincial Laboratory. cooling, packing, in addition to transportation and storage. Also through the contaminated additives which used in the manufacture of chicken meat products (Abd-El-Atti1997; Farghaly, 1998 and Solimman, 2000). Due to the ability to proliferate in a wide range of $\mathrm{pH}$ and temperatures, yeast are of a great importance in spoilage of poultry meat and their products, resulting in different ranging in flavor, color ranging from white, creamy to pink or brown due to pigment production by yeasts, texture (slimness) and odor which make these products unwholesome. Moreover, yeast specially genus Candida have a major public health hazards because it causes several pathogenic lesions in gastrointestinal tract such as stomatitis, diarrhea, gastric disorder, intestinal disturbance and in other organs of the body as vaginitis, pulmonary thrush, meningitis as recorded by Wilson et al. (1981); Bier (1994); Koneman et al. (1997) and Lott and Effat (2001). Saccharomyces cervisiae which is non-spore forming yeast, considered a common colonizer of human respiratory, 
gastrointestinal and urinary tract, as it causes invasive disease in immunocompromised person which could be responsible for pyelonepheritis (Pillai et al., 2014). Killer yeast such as Saccharomyces cervisiae are able to secret a number of toxic protein which are lethal to susceptible yeast strains but not harmful to human or animals. The major killer strains of $\mathrm{S}$. cervisiae belong to the killer class $\mathrm{K} 1$ and $\mathrm{K} 2$ which kill each other but are immune to killer toxins of their own class. Killer yeast phenotype requires presence of two different dsRNA viruses, an L-virus (helper virus) and the toxin-coding (M) (killer virus). L-A helper virus contain 2 open reading frames, the first one encodes a capsule protein $(\mathrm{Gag})$ required for capsid formation and the second one encodes an RNA dependent RNA polymerase (POI) required for viral dsRNA replication (Nurzhan, 2015). There are other killer system in S.cervisiae such as KHS and KHR genes encoded in chromosomal DNA and showing weaker killer activity (Gotoetal., 1990 and Goto et al., 1991). Killer yeasts and their toxins have many potential applications in environmental, medical and industrialbiotechnology. Killer yeast strains can be a problem in commercial processing because they can killdesirable strains. So it's necessary to detect the fungal spoilage at early stages (Dillon and Board, 1991 and Frazier and Westhoff, 1995). Killer yeast strains not being restricted to $S$. cervisiae, it could found in other genera including Candida, Cryptococcus, Debaromyces, Pichia. Toxin from all killer strains are protease-sensitive, heat labile and act only in acidic PH values (Maraquina et al., 2002).

Chromagen Candida agar proved to be a useful method for identifying certain yeast species, such as C. albicans and C. krusei as early as 24 hours, while the majority of yeast isolates required 48 hours incubation before the pigmentation became distinctive enough for differentiation. Although, we could not distinguish between C.parapasilosis and. krusei by color, so required another tests for differentiation (Siriorn et al., 2005). Identification of isolates by polymerase chainreaction (PCR) proved more rapid and accurate identification comparing to traditional phenotypic methods (Yamakami et al., 1996).

Therefore, the present study was conducted to evaluate the total yeast count and the mycological profile of chicken meat products collected from Dakhlia governorate supermarkets.

\section{MATERIALS AND METHODS}

Collection of samples: A total of 60 random samples of chicken products represented by luncheons, pane and nuggets (20 of each) were collected from different markets at Dakhlia governorate. Samples were transferred to the laboratory in ice- box without delay.

Preparation of samples: Twenty five grams of each samples were mixed with $225 \mathrm{ml}$ of sterile peptone water $0.1 \%$ to give dilution of $10^{-1}$ from which further dilution were prepared (APHA, 2001).

Total yeast count: $1 \mathrm{mlfrom}$ each dilution was transfer aseptically to sterile petri dishes contain Sabaroud's dextrose agar(SDA) (Oxoid) at $45^{\circ} \mathrm{C}$ supplemented with $0.05 \mathrm{mg}$ chloramphenicol $/ \mathrm{ml}$, then mixed thoroughly and allowed to solidified, the plates were incubated at $25 \mathrm{C}^{\circ}-28^{\circ} \mathrm{C}$ for $3-4$ days then the yeast colonies were enumerated according to (APHA, 1992).

Isolation and identification of yeast according to (Koneman et al., 1997; Isenberg and Henry 2004; David et al., 2007 and Sivakumar et al., 2008): Yeast colonies were isolated on SDA agar and incubated at $30^{\circ} \mathrm{C}-37^{\circ} \mathrm{C}$ for $72 \mathrm{hs}$.

\section{Identification of suspected yeast isolates: 1-Phenotypic methods: \\ 1.1. Macro morphological characters}

A- Macro morphological characters of yeaston SDA (David et al., 2007; Taha, 2011 and Markey et al., 2013): Gross appearance of the colonies was described considering their size, consistency and surface color.

B- Cultivation on chromogenic candida agar (CCA) for identification of Candida species. Loop full from yeast colonies that identified microscopically by rice agar with $1 \%$ Tween 80 was inoculated on chromogenic candid a agar for $24-48 \mathrm{hs}$ at $30^{\circ} \mathrm{C}$ $35^{\circ} \mathrm{C}$. The colonies color were described with reference to the color formula guides as shown in Table (1).

Table 1: Interpretation of identification of Candida species by CCA

\begin{tabular}{ll}
\hline \multicolumn{1}{c}{ species } & Color \\
\hline C. albicans & Green \\
\hline C.tropicalis & metallic blue \\
\hline C.krusei & Purple \\
\hline C.parapasilosis & Creamy white to light pink \\
\hline Trichosporium & Light blue \\
\hline C.galabrata & Creamy white to light pink \\
\hline Rhodotorula & Orang-pink \\
\hline S. cervisae & Violet \\
\hline
\end{tabular}




\subsection{Micro morphological characters:}

- Slid mount technique: Using cotton blue stain to detect yeast cells. Candida albicans colonies produced thin walled, budding yeast cells and gram's stain to detect gram positive large spherical yeast cells.

- Microscopical examination on rice agar contained tween 80(RAT80):

A thin layer agar were streaked out with yeast to be identified in 3 lines then covered with sterile cover slip. After incubation at $25^{\circ} \mathrm{C}$ for $48 \mathrm{hrs}$, the plates were examined for the presences of blastospores, pseudohyphae, arthrospores and chlamydospores. The identification and differentiation into genera according to (Taha, 2011).

\section{2- Biochemical and physiological tests:}

Sugar fermentation, Sugar assimilation, nitrateassimilation and urea's test according to (Koneman et al., 1997 and David et al., 2007).

- Demonstration of germ tube test (David et al., 2007 and Markey et al., 2013). Avery small inoculum of yeast colonies was suspended in $0.5 \mathrm{ml}$ serum of sheep or normal human in test tube. The tube was incubated at $37^{\circ} \mathrm{C}$ for $1-3 \mathrm{hrs}$. One drop from each serum suspension was placed on a clean slid and cover with cover slip and examined microscopically under low power for detection of pseudomycelium, pseudogerm tubes appearea as small tubes projecting from some of the yeast cells, this is the characteristic of C. albicans.

3- Identification of yeast species by polymerase chain reaction $(\mathrm{PCR})$ :

A- Nucleic acid extraction: DNA extraction from samples was performed using QIAamp DNeasy Plant Mini kit (Qiagen, Germany, GmbH). Briefly, $200 \mu \mathrm{l}$ of the sample was added to $400 \mu \mathrm{l}$ Buffer AP1 and 4 $\mu \mathrm{l}$ RNase A stock solution $(100 \mathrm{mg} / \mathrm{ml})$. The mixture was incubated for $10 \mathrm{~min}$ at $65^{\circ} \mathrm{C}$ and mixed 2 or 3 times during incubation by inverting tube. Then, 130 $\mu \mathrm{l}$ Buffer P3 was added to the lysate, mixed and incubated for $5 \mathrm{~min}$ on ice. The lysate was centrifugated for $5 \mathrm{~min}$ at $14,000 \mathrm{rpm}$ and then pipetted into the QIAshredder Mini spin column (lilac) placed in a $2 \mathrm{ml}$ collection tube, and centrifugated for $2 \mathrm{~min}$ at $14,000 \mathrm{rpm}$. The flowthrough fraction from was transferred into a new tube without disturbing the cell-debris pellet and then applied to silica column. The lysate was then washed and centrifuged following the manufacturer's recommendations. Nucleic acid was eluted with $50 \mu \mathrm{l}$ of elution buffer provided in the kit.

B- Oligonucleotide Primers. Primers used were supplied from Metabion (Germany) and are listed in Table (2).

Table (2): Primers sequences, target genes, amplicon sizes and cycling conditions for conventional PCR.

\begin{tabular}{|c|c|c|c|c|c|c|c|c|}
\hline \multirow[b]{2}{*}{$\begin{array}{l}\text { Target } \\
\text { gene }\end{array}$} & \multirow{2}{*}{$\begin{array}{l}\text { Primers } \\
\text { sequences }\end{array}$} & \multirow{2}{*}{$\begin{array}{c}\text { Amplified } \\
\text { segment } \\
\text { (bp) }\end{array}$} & \multirow[b]{2}{*}{$\begin{array}{c}\text { Primary } \\
\text { Denaturation }\end{array}$} & \multicolumn{2}{|c|}{ Amplification (35 cycles) } & \multirow[b]{2}{*}{ Extension } & \multirow[b]{2}{*}{$\begin{array}{c}\text { Final } \\
\text { extension }\end{array}$} & \multirow[b]{2}{*}{ Reference } \\
\hline & & & & $\begin{array}{c}\text { Secondary } \\
\text { denaturation }\end{array}$ & Annealing & & & \\
\hline \multirow[t]{3}{*}{ KHS } & $\begin{array}{l}\text { AAGCATCCGA } \\
\text { AACAGTACT }\end{array}$ & 919 bp & $\begin{array}{l}94^{\circ} \mathrm{C} \\
5 \mathrm{~min} .\end{array}$ & $\begin{array}{l}94^{\circ} \mathrm{C} \\
30 \mathrm{sec} .\end{array}$ & $\begin{array}{c}53^{\circ} \mathrm{C} \\
50 \mathrm{sec} .\end{array}$ & $\begin{array}{l}72^{\circ} \mathrm{C} \\
50 \mathrm{sec} .\end{array}$ & $\begin{array}{l}72^{\circ} \mathrm{C} \\
10 \mathrm{~min} .\end{array}$ & \multirow[t]{9}{*}{$\begin{array}{l}\text { Suga } e t \\
\text { al., } 2002\end{array}$} \\
\hline & TCAAGGATGC & & & & & & & \\
\hline & TGCTAAGCTG & & & & & & & \\
\hline \multirow[t]{6}{*}{ pelA } & ATCGAATTCA & $727 \mathrm{bp}$ & $94^{\circ} \mathrm{C}$ & $94^{\circ} \mathrm{C}$ & $55^{\circ} \mathrm{C}$ & $72^{\circ} \mathrm{C}$ & $72^{\circ} \mathrm{C}$ & \\
\hline & TGAAGTTCAC & & $5 \mathrm{~min}$. & $30 \mathrm{sec}$. & $45 \mathrm{sec}$. & $45 \mathrm{sec}$. & $10 \mathrm{~min}$. & \\
\hline & TGCTGCTTT & & & & & & & \\
\hline & ACGGAATTCG & & & & & & & \\
\hline & CAGCTCGTGG & & & & & & & \\
\hline & TGGAGCCAGT & & & & & & & \\
\hline \multirow{5}{*}{$\begin{array}{c}\text { C. } \\
\text { Albicans } \\
\text { ITS }\end{array}$} & GGTTTGCTTGA & \multirow[t]{5}{*}{$109 \mathrm{bp}$} & $94^{\circ} \mathrm{C}$ & $94^{\circ} \mathrm{C}$ & $50^{\circ} \mathrm{C}$ & $72^{\circ} \mathrm{C}$ & $72^{\circ} \mathrm{C}$ & \multirow{5}{*}{$\begin{array}{l}\text { Tarini } \\
\text { et al., } \\
2010\end{array}$} \\
\hline & AAGACGGTAG & & $5 \mathrm{~min}$. & $30 \mathrm{sec}$. & $30 \mathrm{sec}$. & $30 \mathrm{sec}$. & $7 \mathrm{~min}$. & \\
\hline & AGTTTGAAGA & & & & & & & \\
\hline & TATACGTGGT & & & & & & & \\
\hline & $\mathrm{AG}$ & & & & & & & \\
\hline
\end{tabular}

C- PCR amplification: Primers were utilized in a 25- $\mu 1$ reaction containing $12.5 \mu 1$ of Emerald Amp Max PCR Master Mix (Takara, Japan), $1 \mu$ of each primer of 20 pmol concentrations, $4.5 \mu \mathrm{l}$ of water, and $6 \mu \mathrm{l}$ of DNA template. The reaction was performed in an applied biosystem 2720 thermal cycler.

\section{D- Analysis of the PCR Products:}

The products of PCR were separated by electrophoresis on $1.5 \%$ agarose gel (Applichem, Germany, GmbH) in 1x TBE buffer at room temperature using gradients of $5 \mathrm{~V} / \mathrm{cm}$. For gel analysis, $15 \mu \mathrm{l}$ of the products was loaded in each gel slot. A gene ruler 100 bp DNA Ladder (Fermentas) and a gelpilot 100 bp ladder (Qiagen, Germany, $\mathrm{GmbH}$ ) were used to determine the fragment sizes. The gel was photographed by a gel documentation system (Alpha Innotech, Biometra) and the data was analyzed through computer software.

- Statistical analysis: The obtained data were analyzed using Analysis of Variance (ONE WAY ANOVA) SPSS according to Sabine and Brian (2014). 


\section{RESULTS}

Table 3: Statistical analytic results of total yeast count (cfu/gm) of examined chicken product samples $(\mathrm{n}=20$ of each).

\begin{tabular}{lccc}
\hline Product /Count & Min & Max & Mean \pm S.E. \\
\hline Luncheon & $1 \times 10^{2}$ & $3 \times 10^{4}$ & $7.1 \times 10^{3} \pm 3.1 \times 10^{3}$ \\
\hline Pane & $2 \times 10^{2}$ & $7.4 \times 10^{5}$ & $1.8 \times 10^{5} \pm 8.2 \times 10^{4}$ \\
\hline Nuggets & $1 \times 10^{3}$ & $1.4 \times 10^{7}$ & $2.4 \times 10^{6} \pm 1.4 \times 10^{6}$ \\
\hline
\end{tabular}

Significant difference between luncheon and nugggets $(\mathrm{P} \leq 0.05)$

\section{Mean total Yeast count in examined chicken}

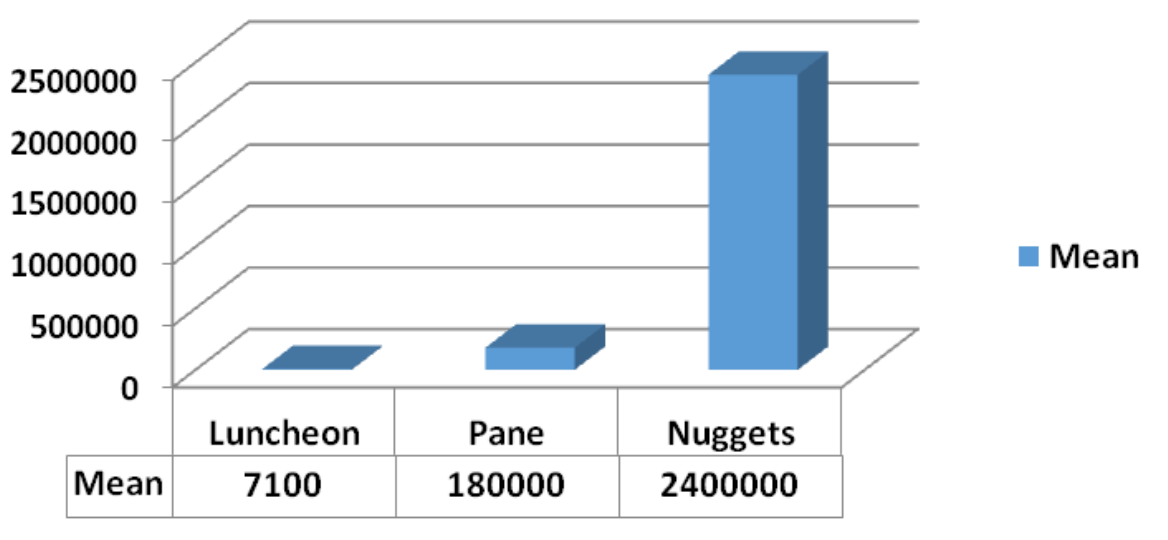

Fig. 1: Mean Yeast count in examined chicken products.

The obtained results in Table (3) and Fig. (1) revealed that the mean yeast count (cfu /gm) were $7.1 \times 10^{3} \pm 3.1 \times 10^{3}, \quad 1.8 \times 10^{5} \pm 8.2 \times 10^{4}$ and $2.4 \times 10^{6} \pm$ $1.4 \times 10^{6}$ for chicken luncheon, pane and nuggets, respectively. There was a significant difference between total yeast count of chicken luncheon and nuggets.

Table 4: Incidence of isolated yeast genera in chicken meat products $(n=20$ of each)

\begin{tabular}{|c|c|c|c|c|c|c|c|c|}
\hline \multirow{2}{*}{$\begin{array}{l}\text { Sample } \\
\text { Yeast } \\
\text { Species }\end{array}$} & \multicolumn{2}{|c|}{ Luncheon } & \multicolumn{2}{|c|}{ Pane } & \multicolumn{2}{|c|}{ Nuggets } & \multicolumn{2}{|c|}{ Total } \\
\hline & $\mathbf{N}$ & $\%$ & $\mathbf{N}$ & $\%$ & $\mathbf{N}$ & $\%$ & $\mathbf{N}$ & $\%$ \\
\hline Candida & 11 & 55 & 17 & 85 & 19 & 95 & 47 & 78.3 \\
\hline Rhodotorula & 5 & 25 & 7 & 35 & 8 & 40 & 20 & 33.3 \\
\hline Saccharomyces & 3 & 15 & 4 & 20 & 4 & 20 & 11 & 18.3 \\
\hline Trichosporon & - & - & 1 & 5 & 2 & 10 & 3 & 5 \\
\hline
\end{tabular}




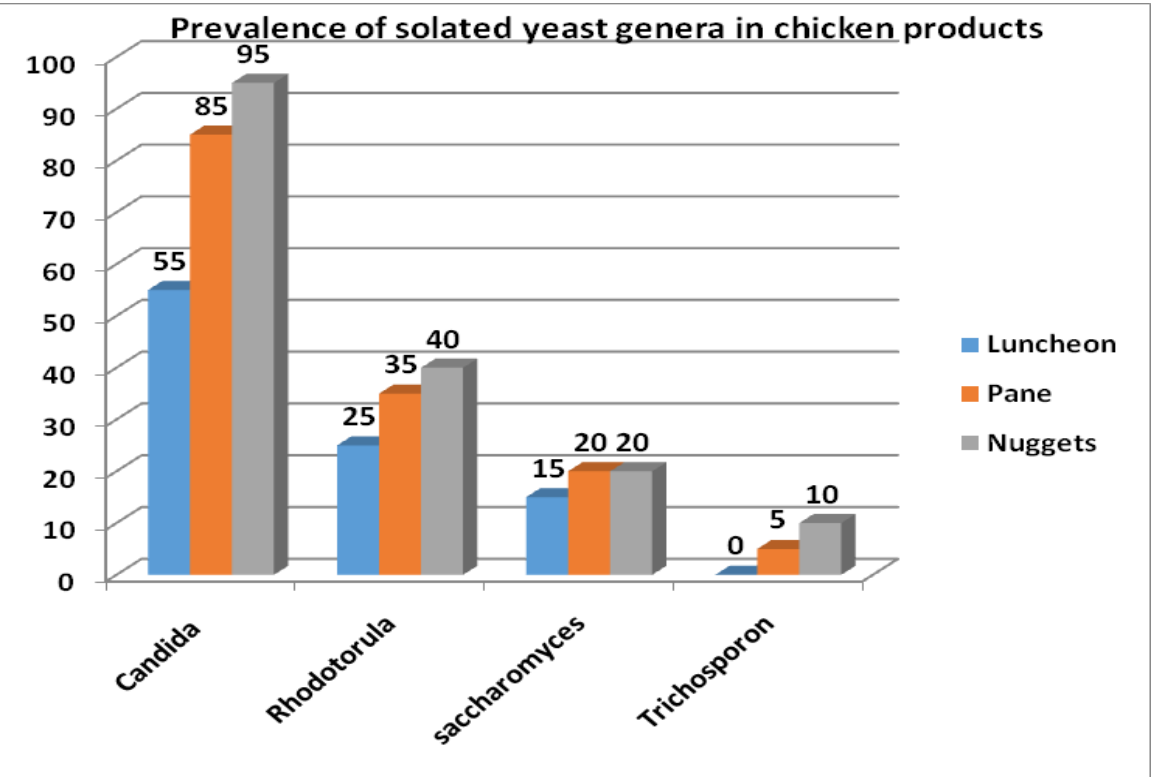

Fig. 2: Prevalence of isolated yeast genera from examined chicken products

The results in Table (4) and Fig. (2) revealed that the predominant yeast genera isolated from examined luncheon, pane and nuggets were Candida 11(55\%), $17(85 \%), 19(95 \%)$ followed by Rhodotorula $5(25 \%), 7(35 \%), 8(40 \%)$, Saccharomyces 3(15\%), $4(20 \%), 4(40 \%)$ and lastly, Trichosporon with incidence of $0(0 \%), 1(5 \%), 2(10 \%)$, respectively. Concerning the proportion of yeast genera individually compared to other isolates from chicken luncheon, pane and nuggets as declared in Table (5), Candida species represented by $14(58.3 \%)$,
$22(59.4 \%), 25(56.8 \%)$ with the highest total incidence $61(58 \%)$ followed by Rhodotorula $7(29.1 \%), 11(29.7 \%), 13(29.5 \%)$ with total incidence $31(29.5 \%)$ then Saccharomyces 3(12.5\%), 3(8.1\%), $4(9.1 \%)$ with total incidence $10(9.5 \%)$, finally Trichosporon $0(0 \%), 1(2.7 \%), 2(4.5 \%)$ with the lowest total incidence $3(2.9 \%)$, respectively. Also Table (5) showed that chicken nuggets have the highest number of isolated yeast genera (44) followed by chicken pane (37) then chicken luncheon (24).

Table 5: Number and percentage of isolated genera in examined chicken meat products in relation to the total isolates ( $n=20$ of each).

\begin{tabular}{lcccccccc}
\hline \multirow{2}{*}{$\begin{array}{l}\text { Samples } \\
\text { yeast species }\end{array}$} & \multicolumn{2}{c}{ Luncheon } & \multicolumn{2}{c}{ Pane } & \multicolumn{2}{c}{ Nuggets } & \multicolumn{2}{c}{ Total } \\
\cline { 2 - 10 } & $\mathrm{N}$ & $\%$ & $\mathrm{~N}$ & $\%$ & $\mathrm{~N}$ & $\%$ & $\mathrm{~N}$ & $\%$ \\
\hline Candida & 14 & 58.3 & 22 & 59.5 & 25 & 56.8 & 61 & 58 \\
\hline Rhodotorula & 7 & 29.1 & 11 & 29.7 & 13 & 29.5 & 31 & 29.5 \\
\hline Saccharomyces & 3 & 12.5 & 3 & 8.1 & 4 & 9.1 & 10 & 9.5 \\
\hline Trichosporon & - & - & 1 & 2.7 & 2 & 4.5 & 3 & 2.9 \\
\hline Total & 24 & 100 & 37 & 100 & 44 & 100 & 105 & 100 \\
\hline
\end{tabular}

Table 6: Incidence of identified yeast species in chicken meat products ( $n=20$ of each)

\begin{tabular}{|c|c|c|c|c|c|c|}
\hline \multirow{2}{*}{$\begin{array}{l}\text { Sample } \\
\text { Yeast } \\
\text { Speacies }\end{array}$} & \multicolumn{2}{|c|}{ Luncheon } & \multicolumn{2}{|c|}{ Pane } & \multicolumn{2}{|c|}{ Nuggets } \\
\hline & $\mathbf{N}$ & $\%$ & $\mathbf{N}$ & $\%$ & $\mathbf{N}$ & $\%$ \\
\hline C. albicans & 8 & 40 & 15 & 75 & 17 & 85 \\
\hline C.tropicalis & 3 & 15 & 2 & 10 & 4 & 20 \\
\hline C. parapasilosis & 2 & 10 & 3 & 15 & 1 & 5 \\
\hline C.krusi & - & - & 1 & 5 & 1 & 5 \\
\hline C.galabrata & 1 & 5 & 1 & 5 & 2 & 10 \\
\hline Rh. Rubra & 4 & 20 & 7 & 35 & 7 & 35 \\
\hline Rh.glutini & 3 & 15 & 4 & 20 & 6 & 30 \\
\hline S. cervisiae & 3 & 15 & 3 & 15 & 4 & 20 \\
\hline Trichosporon & - & - & 1 & 5 & 2 & 10 \\
\hline
\end{tabular}


Table 7: Total number and percentage of identified yeast species in chicken meat products in relation to the total isolates (20 of each).

\begin{tabular}{|c|c|c|c|c|c|c|}
\hline \multirow{2}{*}{$\begin{array}{l}\text { Yeast } \\
\text { Speacies }\end{array}$} & \multicolumn{2}{|c|}{ Luncheon } & \multicolumn{2}{|c|}{ Pane } & \multicolumn{2}{|c|}{ Nuggets } \\
\hline & $\mathbf{N}$ & $\%$ & $\mathbf{N}$ & $\%$ & $\mathbf{N}$ & $\%$ \\
\hline C. albicans & 8 & 33.3 & 15 & 40.5 & 17 & 38.6 \\
\hline C.tropicalis & 3 & 12.5 & 2 & 5.4 & 4 & 9.1 \\
\hline C. parapasilosis & 2 & 8.3 & 3 & 8.1 & 1 & 2.3 \\
\hline C.krusi & - & - & 1 & 2.7 & 1 & 2.3 \\
\hline C.galabrata & 1 & 4.2 & 1 & 2.7 & 2 & 4.5 \\
\hline Rh. Rubra & 4 & 16.7 & 7 & 18.9 & 7 & 15.9 \\
\hline Rh.glutini & 3 & 12.5 & 4 & 10.8 & 6 & 13.6 \\
\hline S. cervisiae & 3 & 12.5 & 3 & 8.1 & 4 & 9.1 \\
\hline Trichosporon & - & - & 1 & 2.7 & 2 & 4.5 \\
\hline Total & 24 & 100 & 37 & 100 & 44 & 100 \\
\hline
\end{tabular}

Concerning yeast species identified from Chicken Luncheon, pane and nuggets Table (6) showed that Candida albicans were the most predominant species which isolated from $(40 \%, 75 \%$, and $85 \%)$ of examined luncheon, pane and nuggets samples, respectively. While Trichosporon was the lowest species which isolated from $(0 \%, 5 \%$ and $10 \%)$, respectively. The results illustrated in Table (7) showed that concerning to chicken luncheon, Candida isolates identified as C.albicans 8 (33.3\%), C.parapasilosis 2(8.3\%), C.tropicalis 3(12.5\%), C.galabrata $1(4.2 \%)$, while Rhodotorula identified as Rh. rubra 4 (16.7\%), Rh.glutini 3(12.5\%) wherease Saccharomyces identified as S. cervisiae 3(12.5\%). Dealing with chicken pane, the isolates identified as C. albicans 15(40.5\%), C. tropicalis 2(5.4\%), C.parapasilosis 3(8.1 \%), C. galabrata 1(2.7\%), C.krusi 1(2.7 \%), Rh. rubra 7(18.9\%), Rh. Glutini
4(10.8\%), S. cervisiae 3(8.1\%) and Trichosporon sp. $1(2.7 \%)$. Regarding to chicken nuggets the isolates identified as C.albicans 17(38.6\%), C.tropicalis 4(9.1\%), C. parapasilosis 1 (2.3\%), C.galabrata 2(4.5\%) C.krusi 1(2.3\%), Rh. Rubra 7(15.9\%), Rh. glutini 6(13.6 \%), S.cerivisae 4 (9.1\%) and Trichosporon species $2(4.5 \%)$.

In concerning with PCR examination, the primer used designed for amplification of the ITS region (Tarini et al., 2010). Table (8) showed, all examined 6 samples were successfully amplified a product of $109 \mathrm{pb}$ and give +ve C.albicans with PCR examination (figure10). While 2 samples amplified a products of $919 \mathrm{bp}$ and interpreted as positive killer gene (KHS) of S.cervisiae. Wherease, one sample amplified a product of $727 \mathrm{bp}$ and give positive of killer gene (pelA) (figure11).

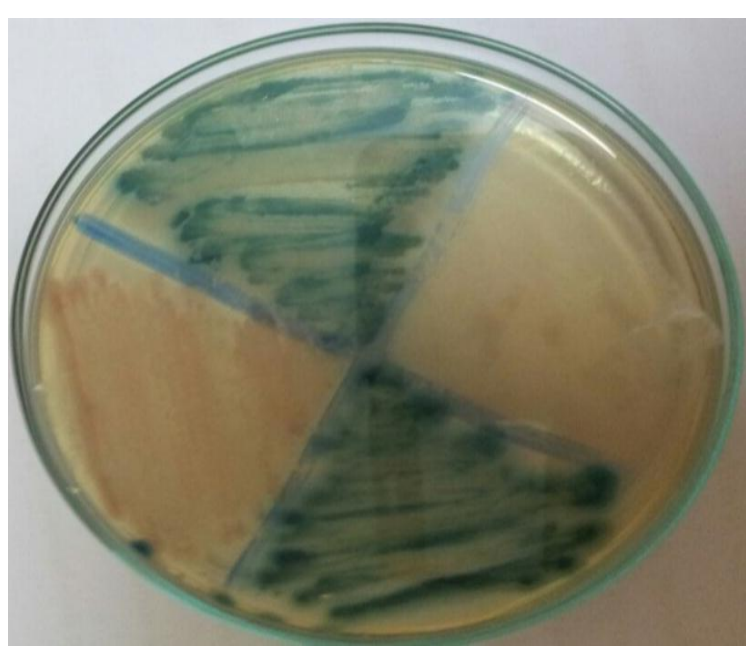

Fig. 3: Candida albicans green, C.parapasilosis white creamy to light pink on CCA

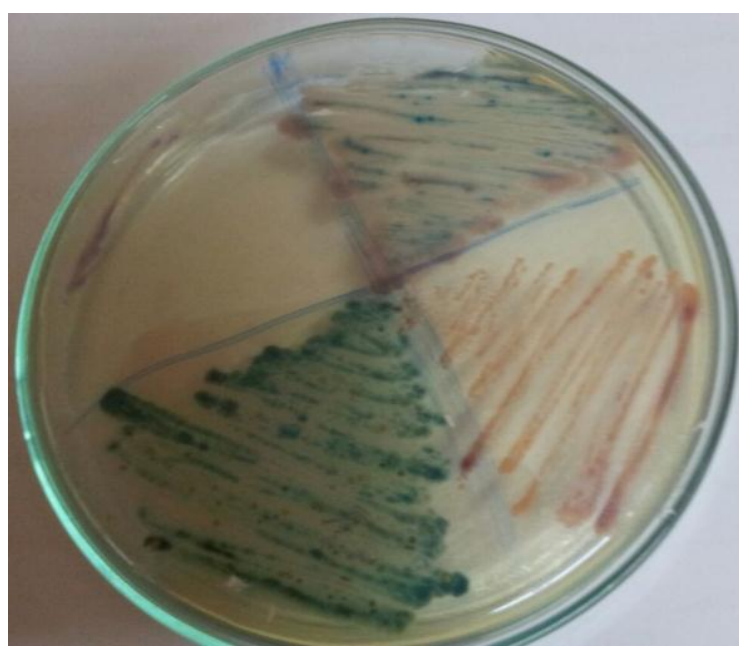

Fig. 4: Candida albicans green, C.tropicalis blue, C.krusi pink, C.galabrata and C. Parapassilosis white creamy to light pink on CCA 


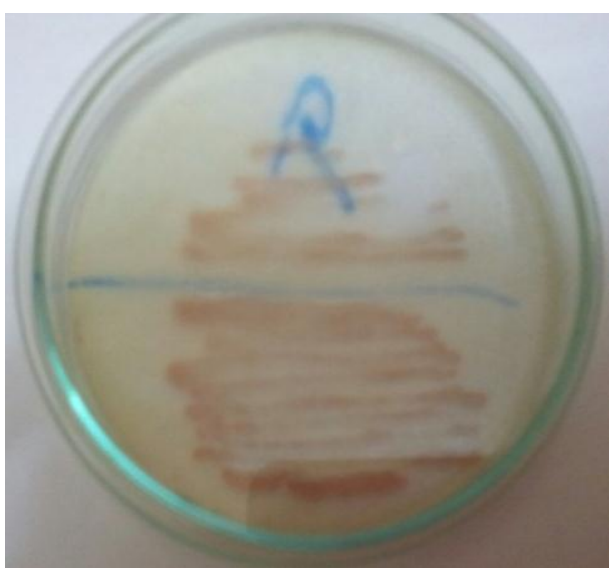

Fig. 5: Rhodotorula orange -pink on CCA

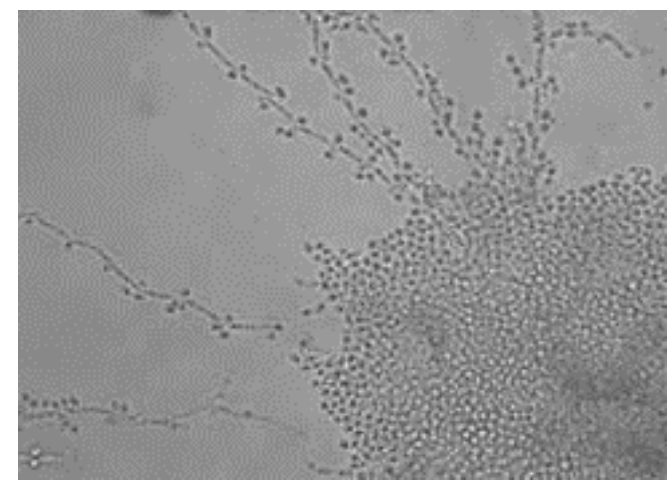

Fig. 7: C. parapasilosis on ART showed giant pseudohyphae with few blastospores

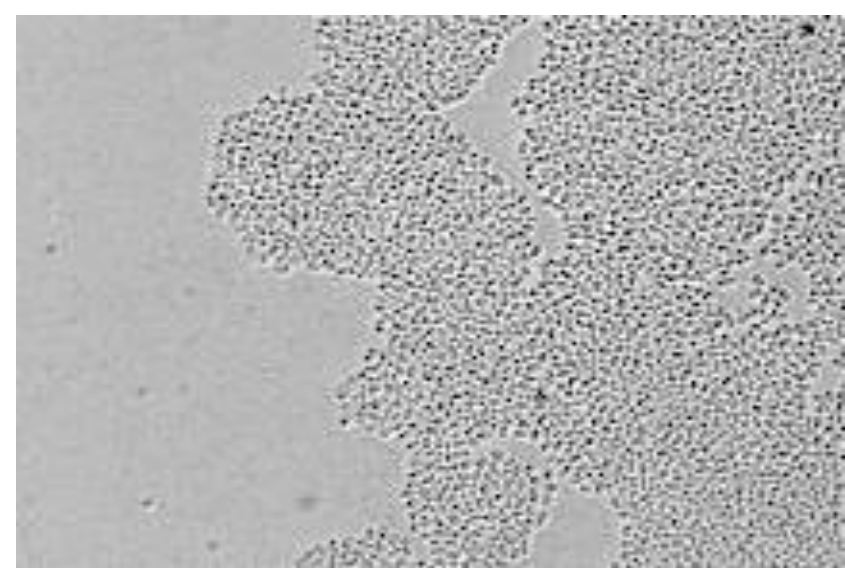

Fig. 6: $C$. galabrata on RAT showing oval budding yeast cells without pseudohyphae

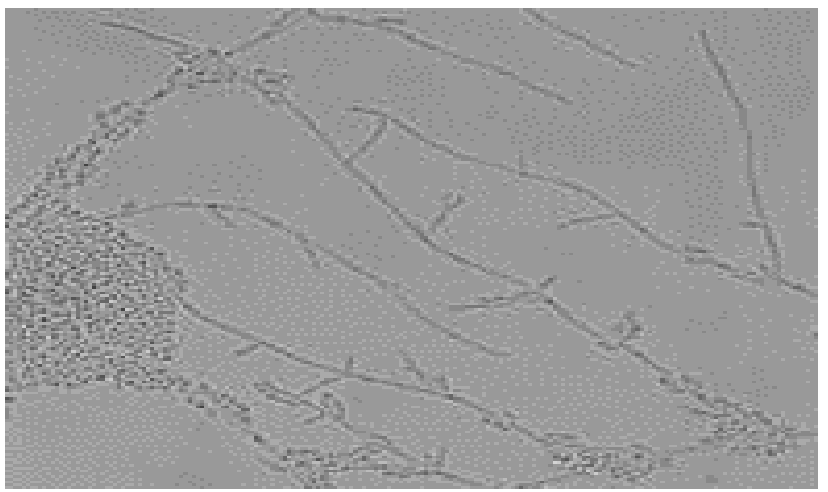

Fig. 8: C.krusei on RAT showed primitive pseudohyphae (tree like branching) with eleptical rice like blastospores

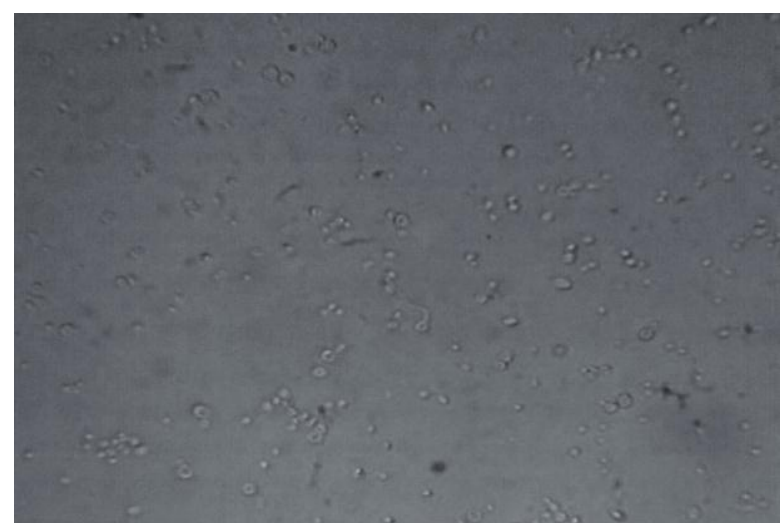

Fig. 9: Microscopic germ tube test, pseudogerm tube appears from some yeast cells which is characteristic of C.albicans

Table 8: Identification of yeast isolates by polymerase chain reaction (PCR)

\begin{tabular}{lccc}
\hline Sample & \multicolumn{3}{c}{ Results } \\
\cline { 2 - 4 } & C. albicans ITS & KHS & pelA \\
\hline 1 & + & - & - \\
\hline 2 & + & + & - \\
\hline 3 & + & - & + \\
\hline 4 & + & + & - \\
\hline 5 & + & - & - \\
\hline 6 & + & - & - \\
\hline
\end{tabular}




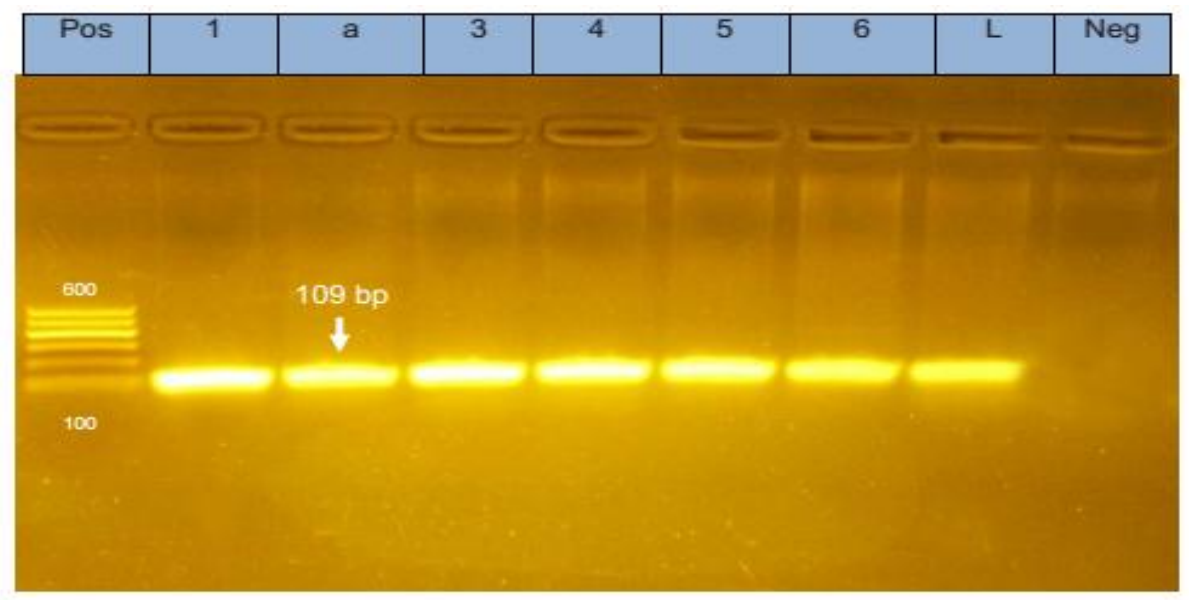

Figure (10): C.albicans ITS

Lane L.: 100-600bp DNA ladder

Lane pos.: positive control at $109 \mathrm{bp}$, Lane $\mathbf{N} .:$ negative control

Lane1-6: positive C.albicans

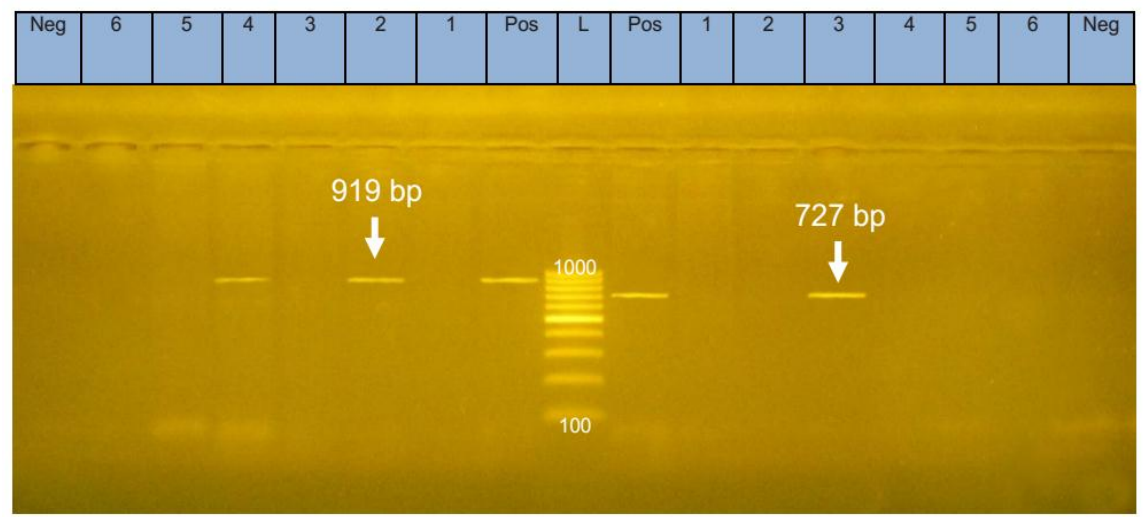

Figuer (11): Killer genes of yeast cells ITS1

Lane L.: 100-1000 bp DNA ladder, LaneN: negative control

Lane pos.: Positive control at 919bp, 727bp, Lane 2,4: positive KHS, Lane3: positive Lane 2,4: positive KHS, Lane3: positive pelA

\section{DISSCUSION}

The mean yeast count (cfu /gm) were $7.1 \times 10^{3} \pm 3.1 \times 10^{3}, \quad 1.8 \times 10^{5} \pm 8.2 \times 10^{4}$ and $2.4 \times 10^{6} \pm$ $1.4 \times 10^{6}$ for chicken luncheon, pane and nuggets, respectively. The results obtained from total yeast count of chicken pane and nuggets seem to be in agreement with that recorded by Abd El-Azizand Mahmud (2005) and Ibrahim et al. (2014). Concerning chicken luncheon samples, the results achieved seems to be in agreement with that recorded by Ismail (1995) and Abd -El Rhman et al. (2013) while higher results recorded by Samaha and Abd ElHafeiz (1997), Abd-El Aziz and Mahmoud (2005), El-Tabiy (2006), Saleh and Salah El Dien (2006), Asefa et al. (2010), Ouf et al. (2010) and Sharaf and Sabra (2012). These variationscould be attributed to the applied hygienic measures, type and amount of additives used in manufacturing of chicken luncheon, and the time and temperature of exposure of the products. Our results pointed out that chicken nuggets was the most contaminated products with yeast followed by chicken pane, while chicken luncheon was the lowest contaminated product with yeast. The highest yeast count in chicken nuggets may be attributed to the use of raw chicken meat of bad quality as well as unhygienic conditions during slaughtering, handling, processing, storage and transport of these chicken products. Regardless the type of chicken products the minimum yeast count was $1 \times 10^{2}$, while the maximum yeast count was $1.4 \times 10^{7}$. Nearlysimilar results were obtained by (Jay, 1978, Edris et al., 1992, Ismail, 1995 and Mahmoud and El-Taher, 2001).

The hight proportion of candida yeast genera in all chicken product samples as mentioned in table (4) were inagreement with those observed by (Ismail, 1995; Vilioen et al., 1998; Mahmoud and El-Taher, 2001; Basyoni; 2003 and Abd El-Rhman et al., 2013). Table (5) revealed that Candida have the highest total incidence $61(58 \%)$, followed by Rhodotorula with total incidence $31(29.5 \%)$ then Saccharomyces 3 $(12.5 \%)$ finally Trichosporon with lowest total 
incidence $3(2.9 \%)$. These results nearly similar to that obtained by Abd El-Rhmanand Ekhateib (1993); Ismail (1995); Pitt and Hocking (2000); Mohamoud and El-Taher (2001); Abd El- Aziz and Mahmoud (2005), El-Tabiy (2006); Hammad et al. (2006); Asefa et al. (2010); Ouf et al. (2010) and AbdElRhman et al. (2013). The results of mycological identification of yeast genera revealed that Candida albicans was the most predominant species isolated from chicken luncheon, pane and nuggets. These results nearly similar to that obtained by Mohmoud and El-Taher (2001); Abd El-AzizMahmoud (2005); El-Tabiy (2006); Ouf et al. (2010) and Abd ElRhman et al. (2013). All examined samples which identified as Candida albicans by traditional standard methods were give positive Candida albicans by PCR examination and 2 sampls interpreted as positive killer gene (KHS) of S.cerviciae while one samples give positive of killer gene (pelA). These results came in accordance with those recorded by Lim and Lee (2000) and Tarini et al. (2010).

\section{CONCLUSION AND RECOMMENDATIONS}

From our results we can concluded that Chicken meat products were subjected to the contamination by various type of yeast species which have public health hazard. Therefore, this study was designed to throw spotlight upon yeast isolates from chicken luncheon, pane and Nuggets, studying their culture, macroscopic, microscopic and biochemical characters with special references to identification and genotypic characters of them using PCR which give rapid and accurate results. Accordingly the hygienic quality of chicken meat products must be improved to be safe for human consumption. The contamination must be reduced by implementing satisfactory manufacturing practices and effectively training plant workers in hygienesafety assurance, application of strict hygienic measures during handling, preparation and serving the products.

\section{REFERENCES}

Abd El-Aziz H.A.A. and Mahmoud, Y.A. (2005): Antiyeast effect of some plant extracts on yeasts contaminating processed poultry products in Egypt. Czech J. of Food Science.2:12-19.

Abd el-Rhman, E. and El-Khateib, T. (1993): Signifigance of occurrence of mould and yeast in frozen ground beef. Archiv fur Lebensmittel hyagien, 444:105-128.

$A b d-E l-A t t i, N$. (1997): Some mycological studies on meat cold store M.V.SC. Thesis. Fac. Vet. Med. Suez Canal University.

Abd-Elrahman, H.D.; Soliman, S.A. and Rahal, E. (2013): Prevalence of yeast in chicken and their products SCVMJ.111 (2): 1-11.
Abo Hussein, R.A. (2007): Detection of food mediated pathogens insomemeat and chicken products by using recent techniques. Ph.D. Thesis (meat hygiene). Faculty of Vet. Med. Banha University.

APAH "American Public Health Association" (1992): Compendium of methods for microbiological examination of foods. American Public Health Association, Washington, D.c.USA.105 (4):100-101.

APAH "American Public Health Association" (2001): Compendium of Methods for Microbiological Examination of food. $4^{\text {th }}$ Ed., Washington, DC, USA.

Asefa, D.T.; Kure, C.F.; Gjerde, R.O.; Omer, M.K. and Skaar, I. (2010): Fungal growth pattern, Sources and factors of mould contamination in a dry -cured meat production facility. International J. of Food Microbiology 1402 (3): 131-135.

Basyoni, S.R. (2003): Study on the incidence of yeast in some meat products. J. of Egyptian Veterinary Medical Association 63:205-211.

Bier, R.C. (1994): Toxocology of natural occurring chemicals in foods. Hui $\mathrm{YH}$, food borne diseases handbook, vol(3), and disease caused hazard. New York. Marcel Dicker1-186.

David, E.; Davis, S.; Alexiou, H.; Hanke, R. and Bartely, R. (2007): Description of Medical Fungi. Second Ed. Bibliogrphynce. $4^{\text {th }}$ Ed. Kendall/Hunt Publishing Co., Dubuque. IA

Dillon, V.M. and Board, R.G. (1991): Yeast association with red meats J. Appl. Bacteriol, 71: 93-108.

Edris, A.M.; El Bardisy, M. and Mousa, M.M. (1992): Studies on microbial status of some marketed meat products with special references to Clostridium perfringens. Egyptian J. of Applied Science 7(12): 19-30

El Tabiy, A.A. (2006): Mycological studies on some processed meat products exposed to sale in markets. Assuit Vet. Med. J.52 (110): 121-131.

Farghaly, R.M. (1998): Some studies on the aflatoxin production aspergilla in meat cold stores. Assuit Vet. Med. J. 31: 111-120.

Frazier, W.C. and Westhoff, D. (1995): Food Microbiollogy, 4th Ed. tata McGraw-hill Publishing Company Limited, New Dellhi.

Goto, K.; Fukuda, H.; Kichise, K. and Hara, S. (1991): Cloning and nucleotide sequence of the kHS killer gen of Saccharomyces cervisiae. Agriculture and Biolgical Chemistry 55(8): 1953-1958.

Goto, K.; Iwatuki, Y.; Kitano, K.; Obata, T. and Hara, S. (1990): Cloning and nucleotide sequence of the KHR killer gene of accharomyces cervisiae. Agriculture and Biological Chemistry 54(4): 979-984

Hammad, A.M. Allah, and H.M.H.G. and Ragheb, R.R. (2006): Mycological and 
mycotoxicological evaluation of turkey carcasses marketed at Sharkia Province. Veterinary Med. J. Giza. 54: 2,405-412.

Ibrahim, M. Hemat; Salem, M. Amany and Mohamed, S. Shnab (2014): Quality evaluation of some locally manufacture chicken meatproducts. Banha Vet. Med. J. 26(2):143-149.

Isenbery, W.D. and Henry, S.C. (2004): Manual of clinical Microbiology. $8^{\text {th }}$ Society of Microbiology.

Ismail, S.A.S. (1995): Study on the significant occurrence of yeast in somemeat products. M.V.S. Thesis, Fac. Vet. Med. Suze Canal University.

Jay, M.J. (1978): Modern Food Microbiology. $2^{\text {nd }}$ ed. D. Van Norstrand, Co. New York.

Koneman, E.; Allen, S.; Janda, W.; Schreckenberger, C. and Winn, W. (1997): Color Atlas and text book of Diagnostic Micfrobiology. Fifth Edition. Lippincott, Philadelphia, New York. 55-73.

Lim, Y.H. and Lee, D.H. (2000): Method for detection Candida albicans using primer drived from the integrin -like protein gene and INT1 of Candida albicans. J. pf Microbiology, 38(2): 105-108.

Lott, T.J. and Effat, M.M. (2001): Candida albicans. North American population. Microbiology 2001, 147.

Mahmoud, Y.A. and El-Taher, E.G.M. (2001): Yeast contamination of some meat products. Procceding of the $1^{\text {st }}$ Cong. of Food Hyagien and Human health Fac. Vet. Med. Assuit University, 6-8February 2001.

Marky, B.K.; Leonard, F.C.; Archambault, M. and Maguire, D. (2013): Clinical Veterinary Microbiology. Second edition. MOSBY. Elsevier Ltd. B Edinburgh London New York Oxford Philadelphia StLOuis Sydney

Marquina D.; Santos, A. and Peinado, J.M. (2002): Biolog of killer yeast. INT. Microbiol. 5:65-71.

Nurzhan, K. (2015): Killer yeast or survival instinct. Control (Apple) F. for Genetics. May 182016 (9).47, 101

Ouf, J.M.; Khafaga, N.I.M. and Shabana, S.E. (2010): Incidence of proteolytic and lipolytic moulds and yeasts in some ready to eat products. Assiut Vet. Med. J.56: 126,132-143.

Pillai, U.; Devasahayam, J.; Kurup, A.N. and Lacasse, A. (2014): Invasive saccharomyces cerevisiae infection: A friend turning foe. Saudi J. of kidney diseases and transplantation 25(6)1266-1269.

Pitt, J.J. and Hocking, A.D. (2000): Fungi and Food $2^{\text {nd }}$ Ed. London, Blackie Academic and Professional.
Saleh, M.A. and Salah, El Diien, W.M. (2006): Evalution of fungi in minced and some meat products in Zagazig City markets Zagazig Vet. J. 34 (3): 10-16.

Sabine, L. and Brian, S.E. (2014): A Handbook of statistical analysis using CHAPMAN and HALL/CRC. A Press. User manual SPSS. Inc. /SPSS. Ver. 20.

Samaha, I.A. and Abd El Haeiz, E. (1997): Microbial evaluation of some heat treated chicken products different processing stages. Alexandria J. of Vet. Sci., 13: 321-332.

Sharaf, M. Eman and Sabra, M. Sherifa (2012): Microbiology Department Science Collage, Taif University, KSA Word Applied Sciences Journal 17(5): 593-597.

Sheeded, N.A. (1999): Evaluation of cooking chicken meat. Thesis, Fac.Agri. Cairo University.

Siriorn, P.; Paritpokee, H. and Gary, P. (2005): Rapid identification of yeast isolates using BD BBL Chrom agar candida. As presented at $105^{\text {th }}$ General Meeting of the American Society Microbiology, 2005. LR894.

Sivakumar, V.G.; Shanksar, P.; Natina, K. and Menon, T. (2008): Use of CHROM agar in the differentiation of common species of Candida. Mycopathologia 67:47=49.

Soliman, Soad (2000): Control of proteolytic and lipolytic yeast in poultry products. Ph.D. Thesis, Department of food hygiene, Faculty of Vet. Med. Suez Canal University.

Suga, H.; Ikeda, S.; Taga, M.; Kageyama, $\quad$ K. and Hyakumachi, M. (2002): Electrophoretic karyotyping and gene mapping of seven formae speciales in Fusarium solani. Curr. Genet. 2002 Jul; 41(4):254-60.

Taha, M. (2011): Medical mycology (Atlas of medically important fungi and dermatomycosis). $1^{\text {st }}$ ed. Mecca, Printing house, Cairo, Egypt.

Tarini, N.M.A.; Wahid, M.H.; Ibrahim, F.; Yasmon, A. and Djauzi, S. (2010): Development of multiplex-PCR assay for rapid detection of Candida spp. Med. J. Indonses. 19(2): 83-87.

Vilioen, B.C.; Georrnaras, I.; Lamprecht, I. and Von Holy, A. (1998): Yeast population associated with processed poultry. Food Microbiology 15: 113-117.

Wilson, N.R.P.; Dyett, E.J. and Janes, C.R. (1981): Meat and meat products. Applied Science publisher. London. New Jersey.

Yamakami, Y.; Hashimoto, A.; Tokimatsu, F. and Nasu, M. (1996): PCR detection of DNA specific for Aspergillus species in serium of patient with invasive aspergillosis. J. Clin. Microbiol. 34: 2464-2468. 


\section{مدى تواجد الخمائر فى بعض منتجات لحوم الدواجن \\ دعاء احد حسين المطرى ، نشوى محد زكى}

Email: doaaelmatry@yahoo.com Assiut University web-site: www.aun.edu.eg

تم اجر اء هذه الدر اسة على • ج عينة من منتجات الدجاج المطهية و النصف مطعية مثل الانثون و البانية و الناجتس تم تجميعها من

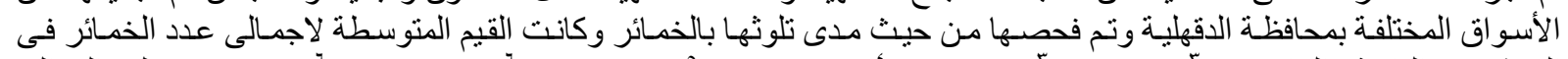

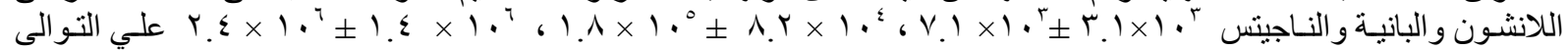

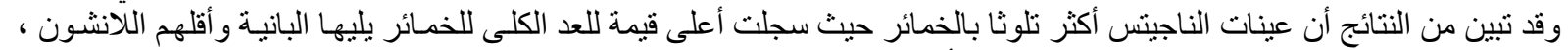

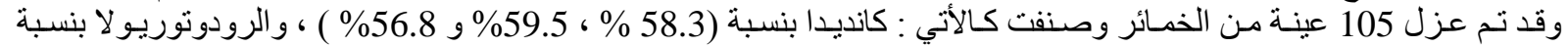

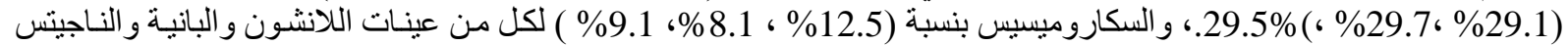

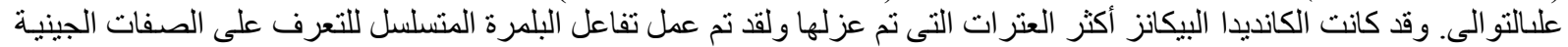

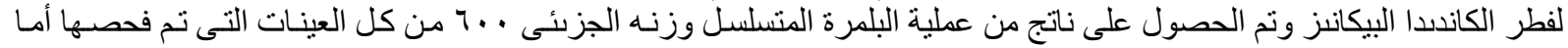

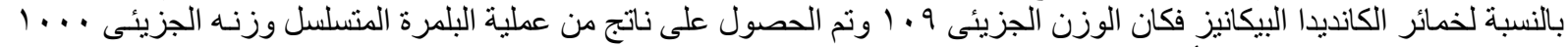

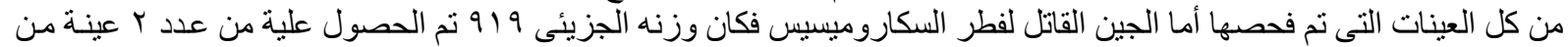

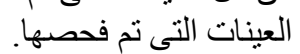

